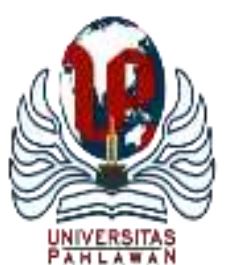

Edukatif : Jurnal Ilmu Pendidikan Volume 4 Nomor 1 Tahun 2022 Halm 278 - 288 EDUKATIF: JURNAL ILMU PENDIDIKAN

Research \& Learning in Education

https://edukatif.org/index.php/edukatif/index

\title{
Meningkatan Motivasi Belajar Peserta Didik pada Pembelajaran Tatap Muka Usai Belajar Online Akibat Pandemi Covid-19
}

\author{
Syarifuddin ${ }^{1 凶}$, St $_{\text {Aisyah }^{2}}$, Yuli Triana ${ }^{3}$ \\ Universitas Lambung Mangkurat ${ }^{1}$, Universitas Terbuka ${ }^{2,3}$ \\ E-mail : syarifuddin@ulm.ac.id ${ }^{1}$, staisyah@ut.ac.id ${ }^{2}$, yuli@ecampus.ut.ac.id ${ }^{3}$
}

\begin{abstract}
Abstrak
Tahun 2021 pembelajaran tatap muka mulai diberlakukan kembali, namun akibat pemebelajaran daring banyak peserta didik mengalami penurunan kemampuan akademiknya. Tujuan Artikel ini untuk menemukan solusi agar peserta didik yang mengalami kejenuhan dalam belajar dan cenderung memperoleh ketidakmajuan dalam hasil belajar dapat terdorong untuk kembali semangat belajar sehingga memiliki prestasi belajar yang bagus juga. Artikel ini menggunakan pendekatan konseptual dengan desain literature review. Hasil yang diperoleh dari beberapa studi leterasi yang dilakukan, peserta didik banyak mengalami penurunan prestasi belajar karna tidak maksimalnya proses pembelajaran yang dilakukan secara daring, peserta didik juga tidak termotivasi mengikuti pembelajaran dengan baik serta banyaknya beban tugas selama proses pembelajaran daring berlangsung. Hal tersebut berimbas pada pembelajaran tatap muka yang sudah dilakukan, peserta didik banyak yang tidak paham tentang materi-materi pembelajaran yang telah diberikan selama proses pembelajaran daring, sehingga perlu adanya inovasi dalam proses penyampaikan materi dikelas agar dapat menarik simpati peserta didik untuk kembali semangat belajar dan termotivasi untuk meningkatkan prestasi belajarnya. Artikel ini menawarkan beberapa metode yang dapat dilakukan untuk menarik simpati dan meningkatkan kemampuan belajar peserta didik berbasis revolusi industri (penggunaan teknologi) dalam proses pembelajaran.
\end{abstract}

Kata Kunci: Motivasi belajar, strategi belajar, pembelajaran tatap muka.

\begin{abstract}
In 2021 face-to-face learning will begin to be implemented again, but due to online learning, many students experience a decline in their academic abilities. The purpose of this article is to find a solution so that students who experience boredom in learning and tend to have progressed in learning outcomes can be encouraged to return to their enthusiasm for learning so that they have good learning achievements as well. This article uses a conceptual approach with a literature review design. The results obtained from several literacy studies that were carried out showed that many students experienced a decrease in learning achievement because the online learning process was not optimal, students were also not motivated to take part in learning well and there were many task loads during the online learning process. This has an impact on the face-to-face learning that has been carried out, many students do not understand the learning materials that have been provided during the online learning process, so there is a need for innovation in the process of delivering material in class in order to attract the sympathy of students to return to the spirit of learning and motivated to improve their learning achievement. This article offers several methods that can be used to attract sympathy and improve students' learning abilities based on the industrial revolution (use of technology) in the learning process.
\end{abstract}

Keywords: learning motivation, learning strategies, face-to-face learning

Copyright (c) 2022 Syarifuddin, St Aisyah, Yuli Triana

$\triangle$ Corresponding author
Email $\quad:$ syarifuddin@ulm.ac.id
DOI $\quad:$ https://doi.org/10.31004/edukatif.v4i1.1700

ISSN 2656-8063 (Media Cetak)

ISSN 2656-8071 (Media Online)

Edukatif : Jurnal Ilmu Pendidikan Vol 4 No 1 Tahun 2022 p-ISSN 2656-8063 e-ISSN 2656-8071 


\section{PENDAHULUAN}

Pada awal kemunculan COVID-19, COVID-19 awalnya diduga adalah penyakit pneumonia, yang memiliki gejala seperti flu pada umumnya. Gejalanya adalah antaranya demam, batuk, letih, tidak nafsu makan dan sesak napas. Namun ternyata COVID-19 berbeda dengan flu biasa dan bahkan COVID-19 dapat berkembang dengan amat cepat sampai dapat mengakibatkan infeksi lebih parah dan gagal organ. Kondisi darurat ini terutama terjadi pada pasien dengan masalah kesehatan sebelumnya. COVID-19 adalah penyakit yang menular. COVID-19 dapat menular dengan mudah melalui batuk atau napas yang dikeluarkan oleh penderita COVID-19. Percikan batuk dan napas oleh penderita COVID-19 yang jatuh ke permukaan benda akan dapat menularkan penyakitnya melalui benda tersebut. Apabila seseorang menyentuh benda atau menghirup percikan tersebut kemudian Ia menyentuh hidung mata atau mulutnya maka Ia dapat tertular COVID-19 (Ciotti et al., 2020; Lone \& Ahmad, 2020). Oleh karena itu, organisasi kesehatan dunia yaitu World Health Organization (WHO) menghimbau untuk menjaga jarak lebih dari 1 meter dari orang lain untuk meminimalisir penularan COVID-19 . Penularan COVID-19 sangatlah cepat sehingga Organisasi Kesehatan Dunia (WHO) menetapkan virus corona atau COVID-19 ini sebagai pandemi pada tanggal 11 Maret 2020.

Status epidemi global atau pandemi ini menandakan penyebaran COVID-19 berlangsung sangatlah cepat hingga hampir tak ada negara di dunia yang dapat terhindar dari virus corona COVID-19 telah menjadi pademi, sehingga pemerintah di bebagai negara telah menerapkan lockdown atau karantina. Pengertian karantina menurut UU Republik Indonesia Nomor 6 tahun 2018 tentang Kekarantinaan Kesehatan adalah pembatasan kegiatan dan/atau pemisahan seseorang yang terpapar penyakit menular sebagaimana ditetapkan dalam peraturan perundang-undangan meskipun belum menunjukkan gejala apapun untuk mencegah kemungkinan penyebaran ke orang di sekitarnya (A. G. Sari, 2020) . Pemerintah Indonesia telah menghimbau untuk tetap di dalam rumah dan mengisolasi diri. Pemerintah Indonesia menerapkan aturan PSBB yang merupakan singkatan dari Pembatasan Sosial Berskala Besar yang dibuat dalam rangka Penanganan COVID197. Hal ini dilakukan dengan harapan virus tidak menyebar lebih luas dan upaya penyembuhan dapat berjalan maksimal. Dalam usaha pembatasan sosial ini pemerintah indonesia telah membatas kegiatan diluar rumah seperti kegiatan pendidikan yang telah dilakukan secara online melalui pembelajaran online.

Pembelajaran online dilakukan dengan memanfaatkan teknologi khususnya internet. Pemvelajaran online dilakukan dengan sistem belajar jarak jauh, dimana Kegiatan Belajar dan Mengajar (KBM) tidak dilakukan secara tatap muka. Pembelajaran dilakukan dengan menggunakan media, baik media cetak (modul) maupun non cetak (audio/video), komputer/internet, siaran radio dan televisi (R. P. Sari, et al,.2021). Disisi lain pembelajaran online banyak menimbulkan problem seperti hasil riset (Ayu, et al.,, 2021) menyatakan bahwa pembelajaran daring tidak berjalan efektif, hasil penyampaian pembelajaran yang diberikan pendidikan juga tidak sepenuhnya dapat ditangkap oleh peserta didik dan peserta didik juga malas untuk mengerjakan tugas. Begitu juga degan hasil riset (Purnomo et al., 2019) penurunan kemampuan peserta didik disebabkan beberapa kendala seperti penguasaan teknologi yang kurang, pembiayaan kouta internet, orang tua yang kewalahan membantu anak belajar, komunikasi antar peserta didik kurang, komunikasi antar guru dan orang tua kurang, serta jam kerja yang menjadi tidak terbatas.

Kedua hasil riset tersebut dapat disimpulkan bahwa dampak pembelajaran online sangat berpengaruh pada proses penurunan kemampuan akademik peserta didik. Demikian juga hasil penelitian Pratama, A. P. (2021) menyatakan bahwa Sebelum pembelajaran Daring rata-rata motivasi belajar peserta didik sebesar $80,8 \%$ dan sesudah pembelajaran Daring rata-rata motivasi belajar anak mengalami penurunan menjadi $64,01 \%$, artinya ada penurunan motivasi peserta didik untuk belajar adalah $16,07 \%$. Sama halnya dengan penelitian ALDIYAH, E. (2021) dan Rinawati, D., \& Darisman, E. K. (2020) menyatakan bahwa pembelajaran daring di masa pandemi Covid-19 membawa perubahan gaya belajar peserta didik dimana terjadi penurunan motivasi belajar peserta didik. Hasil penelitian tersebut memberikan gambaran yang sangat 
jelas bahwa dampak pembelajaran tersebut benar-benar menjadi hal yang sangat serius, dalam hal ini seorang guru dituntut kreatif dan inovatif dalam mengemas perangkat pembelajaran agar mampu menumbuhkan kembali semangat belajar peserta didik serta mampu memberikan motivasi untuk meningkatkan kemampuan akademik peserta didik.

Motivasi belajar menjadi hal yang sangat diperlukan peserta didik untuk kembali menemukan kenyaman dalam proses belajarnya. Motivasi belajar adalah sebuah penggerak atau pendorong yang membuat seseorang akan tertarik belajar secara terus-menerus. Motivasi yang rendah dapat menyebabkan rendahnya keberhasilan dalam belajar sehingga juga akan berdampak pada prestasi belajarnya. Oleh karena itu, dalam artikel ini akan membahas mengenai bagaimana cara meningkatkan motivasi belajar peserta didik pada pembelajaran online akibat pandemi COVID-19 dengan menggunakan media interaktif serta beberapa motode pembelajaran berbasis revolusi industri yang menarik.

\section{METODE PENELITIAN}

Penelitian ini menggunakan pendekatan konseptual dengan desain literature review berupa ulasan, rangkuman, dan pemikiran penulis dari beberapa jurnal,buku dan lain-lain yang berkaitan dengan topik yang dibahas. hal ini dilakukan untuk memperoleh makna baru yang terkandung dalam istilah yang diteliti. Sumber dan pengumpulan data dalam penelitian ini dilakukan dengan menelusuri hasil-hasil riset dan buku yang berkaitan dengan hasil belajar peserta didik pada masa pandemi. Berikut alur pegumpulan datanya:

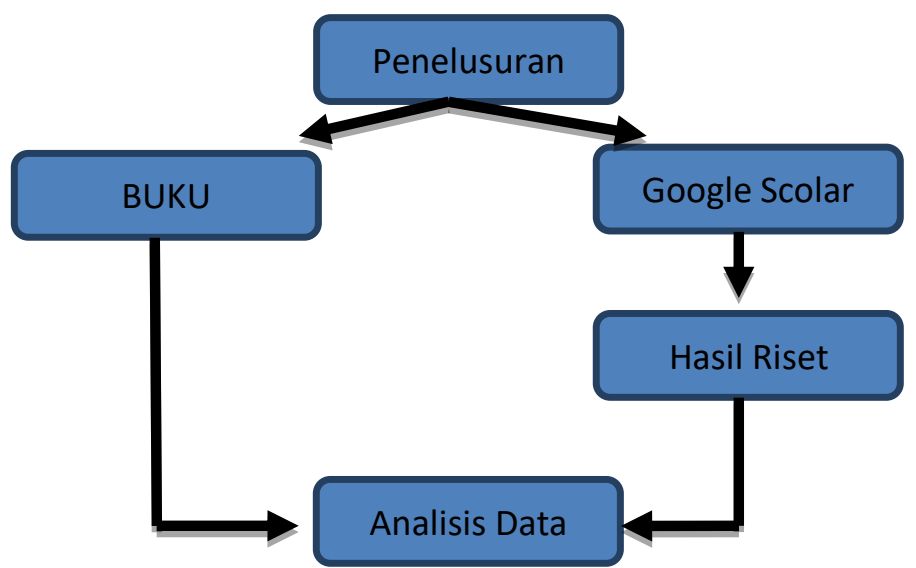

Gambar 1. Skema Pengumpulan Data

Teknik analisa data menggunakan kualitatif yuridis, yaitu dengan melakukan studi terkait hasil belajar peserta didik dimasa pandemi Covid-19 dan menganalisa hubungannya dengan objek penelitian. Pada kegiatan analisis dilakukan penguraian kalimat dan jika sudah terkumpul kemudian dicari persamaan dan perbedaan pada masing-masing artikel lalu dibahas untuk menarik kesimpulan. 
281 Meningkatan Motivasi Belajar Peserta Didik pada Pembelajaran Tatap Muka Usai Belajar Online Akibat Pandemi Covid-19- Syarifuddin, St Aisyah, Yuli Triana

DOI: https://doi.org/10.31004/edukatif.v4i1.1700

\section{HASIL DAN PEMBAHASAN PENELITIAN}

Tabel 1. Hasil riset pada pembelajaran pandemi Covid-19

\begin{tabular}{llll}
\hline \multicolumn{1}{c}{ Judul } & \multicolumn{1}{c}{ Tujuan } & \multicolumn{1}{c}{ Metode } & \multicolumn{1}{c}{ Hasil } \\
\hline Pembelajaran Pada & Sebagai tinjauan & Descriptive & Pembelajaran daring perlu di evaluasi \\
Masa Pademi & umum & content & dan disesuaikan dengan kondisi \\
Covid-19 & terkait pembelajaran & analysis & setempat, mengingat kemampuan \\
$(($ Herliandry, et al., & pada masa pandemic & study & orang tua memberikan fasilitas \\
2020) & COVID-19 & & pembelajaran online berbeda. \\
& & & Kuncinya adalah memaksimalkan \\
& & & kemampuan peserta didik belajar \\
& & & dalam kondisi pandemic seperti ini.
\end{tabular}

Artikel ini mengungkap keadaan peserta didik yang mengikuti pembelajaran daring, kendala yang ditemui peserta didik sangat banyak seperti tidak tersedianya gawai sebagai sumber media, kemampuan peserta didik, kemampuan peserta didik yang terbatas dalam mengoprasikan media pembelajran online dan dukungan orang tua yang minim. Ada 6 kriteria yang dijelaskan dalam penelitian tersebut mengenai keaktifan peserta didik. Peserta didik yang dapat mencapai ke 6 kriteria tersebut hanya ada beberapa saja yang memenuhi kriteria tersebut.

Tabel 2. Hasil riset pada pembelajaran pandemi Covid-19

\begin{tabular}{|c|c|c|c|}
\hline Judul & Tujuan & Metode & Hasil \\
\hline 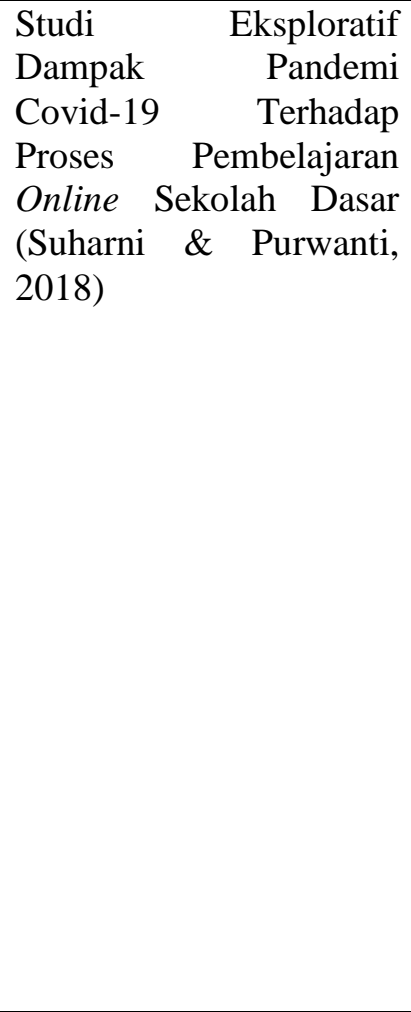 & $\begin{array}{l}\text { mengidentifikasi } \\
\text { mendapatkan informasi } \\
\text { kendala proses belajar } \\
\text { mengajar secara online } \\
\text { di rumah akibat dari } \\
\text { adanya pandemic } \\
\text { COVID-19 }\end{array}$ & $\begin{array}{l}\text { Tudi Kasus Eksplorasi } \\
\text { Dan Pendekatan } \\
\text { Penelitiannya } \\
\text { Menggunakan Metode } \\
\text { Studi Kasus Kualitatif }\end{array}$ & $\begin{array}{l}\text { terdapat beberapa } \\
\text { kendala yang dialami } \\
\text { oleh murid, guru dan } \\
\text { orang tua dalam kegiatan } \\
\text { belajar mengajar online } \\
\text { yaitu penguasaan } \\
\text { teknologi masih kurang, } \\
\text { penambahan biaya } \\
\text { kuota internet, adanya } \\
\text { pekerjan tambahan bagi } \\
\text { orang tua dalam } \\
\text { mendampingi anak } \\
\text { belajar, komunikasi dan } \\
\text { sosialisasi antar siswa, } \\
\text { guru dan orang tua } \\
\text { menjadi berkurang dan } \\
\text { Jam kerja yang menjadi } \\
\text { tidak terbatas bagi guru } \\
\text { karena harus } \\
\text { berkomunikasi dan } \\
\text { berkoordinasi dengan } \\
\text { orang tua, guru lain, dan } \\
\text { kepala sekolah. }\end{array}$ \\
\hline
\end{tabular}

Artikel diatas mengakatan bahwa tolak ukur dalam proses pembelajaran online bisa berhasil atau gagal tergantung gaya belajar yang diberikan. Gaya/cara mengajar tentu sejalan dengan kemampuan seorang pengajar, jika soerang pengajar mampu mengolah pembelajaran daring dengan baik maka akan berdampak 
282 Meningkatan Motivasi Belajar Peserta Didik pada Pembelajaran Tatap Muka Usai Belajar Online Akibat Pandemi Covid-19-Syarifuddin, St Aisyah, Yuli Triana

DOI: https://doi.org/10.31004/edukatif.v4i1.1700

juga terhadap meningkatnya motivasi peserta didik. Maka dapat dikatakan bahawa peran guru menjadi kunci kesuksesan pemlajaran daring.

Tabel 3. Hasil riset pada pembelajaran pandemi Covid-19

\begin{tabular}{|c|c|c|c|}
\hline Judul & Tujuan & Metode & Hasil \\
\hline $\begin{array}{lr}\text { Analisis } & \text { Motivasi } \\
\text { Belajar dan Hasil Belajar } \\
\text { Siswa dimasa } & \text { Pandemi } \\
\text { (Syachtiyani } & \& \\
\text { Trisnawati, 2021) }\end{array}$ & $\begin{array}{l}\text { (1) untuk mengetahui } \\
\text { bagaimana motivasi } \\
\text { belajar siswa di masa } \\
\text { pandemi covid-19 dan } \\
\text { (2) untuk mengetahui } \\
\text { bagaimana } \\
\text { belajar siswa di masa } \\
\text { pandemi covid-19. }\end{array}$ & $\begin{array}{l}\text { penelitian deskriptif } \\
\text { kualitatif } \\
\text { menggunakan } \\
\text { pendekatan kualitatif }\end{array}$ & 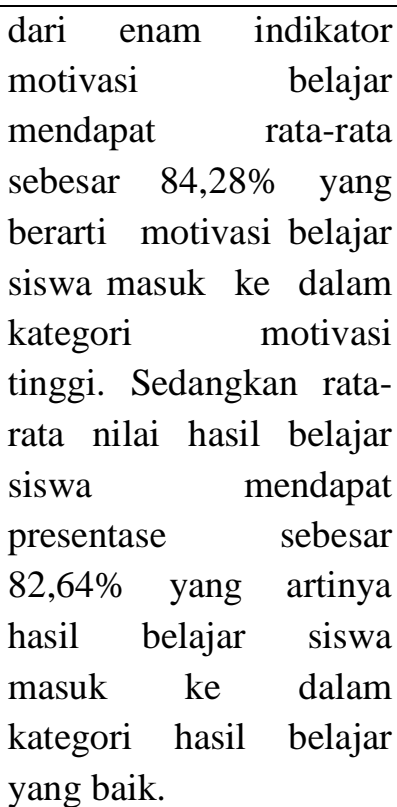 \\
\hline
\end{tabular}

Dari artikel diatas dapat dilihat bahwa pembalajaran daring yang membuat peserta didik dan guru tidak dapat bertatap muka secara langsung. Pembelajaran yang dialihkan ke sistem daring memberikan dampak negatif pada motivasi peserta didik dalam belajar. Ada penurunan motivasi peserta didik selama mengikuti proses pembelajaran daring dikarenaakan faktor lingkungan dirumah. Guru benar-benar dituntut untuk kreatif dan inovatif mengubah gaya belajar sebagai solusinya.

Tabel 4. Hasil riset pada pembelajaran pandemi Covid-19

\begin{tabular}{llll}
\hline \multicolumn{1}{c}{ Judul } & \multicolumn{1}{c}{ Tujuan } & \multicolumn{1}{c}{ Metode } & \multicolumn{1}{c}{ Hasil } \\
\hline Pembelajaran & Mencari tahun & Menggunakan metode & fenomena \\
Daring Dan & bagaimana penerapan & fenomenologi, dimana & yang terjadi \\
Luring Pada Masa & Pembelajaran daring dan & untuk melihat fenomena & dalam \\
Pandemi & pembelajaran luring & yang terjadi & kehidupan di \\
Covid-19. (Pratama, & & dalam & masyarakat peran guru \\
2021) & & kehidupan di & tidak bisa \\
& & masyarakat & \\
& & digantikan \\
& & dengan apapun \\
\hline
\end{tabular}

Pada artikel ini menerangkan bahwa sekolah sudah menggunakan berbagai cara untuk melakukan pembelajaran daring menggunakan media sosial yang membuata peserta didik tertarik dan menyukai proses pembelajarannya. Namun ada kendala juga yang dialami pada penerapannya yaitu berupa tidak adanya gawai yang dimiliki oleh peserta didik sehingga sekolahpun harus melaksanakan pembelajaran luring dengan jumlah kelas $50 \%$ dari keselurahan peserta didik.

Tabel 5. Hasil riset pada pembelajaran pandemic covid-19

\begin{tabular}{|c|c|c|c|c|}
\hline Judul & Tujuan & Metode & & Hasil \\
\hline Problematika & menganalisis & dianalisis & secara & menunjukkan \\
\hline Pembelajaran Daring di & problematika & kualitatif dengan & model & pelaksanaan \\
\hline
\end{tabular}



Akibat Pandemi Covid-19-Syarifuddin, St Aisyah, Yuli Triana

DOI: https://doi.org/10.31004/edukatif.v4i1.1700

\begin{tabular}{lllr}
\hline Masa Pandemi Covid-19 & pembelajaran daring di & interaktif \\
dan Solusi & masa pandemi covid-19 & \\
Pemecahannya (Asmuni, & dan & solusi \\
2020) & pemecahannya.
\end{tabular}

pembelajaran daring di

masa pandemi covid-19

memiliki beragam

problematika yang

dialami guru, peserta

didik, dan orangtua.

Permasalahan dari guru

berupa lemahnya

penguasaan IT dan

terbatasnya akses

pengawasan peserta

didik, dari peserta didik

berupa kekurangaktifan

mengikuti pembelajaran,

keterbatasan fasilitas

pendukung dan akses

jaringan internet,

sementara dari orangtua

berupa keterbatasan

waktu dalam

mendampingi anaknya

di saat pembelajaran

daring. Beragam

permasalahan tersebut

dapat diatasi dengan

meningkatkan

kompetensi penguasaan

IT, pengawasan intensif

dengan melibatkan peran

orangtua, dan

memberikan penugasan

secara manual.

Pada artikel ini diperoleh informasi bahwa kelas virtual atau daring yang memudahkan peserta didik mengaksenya kapanpun dan dimanapun akan mampu membuat peserta didik lebih mandiri dalam belajar. Namun disini juga peran guru kretif dan inovasi juga harus diperhatikan agar sesuai dengan materi-materi yang akan di sampaikan ke peserta didik.

Perbedaan kelima hasil artikel diatas dapat disimpulkan bahwa salah satu faktor yang dapat menunjang pelaksanaan kegiatan belajar mengajar adalah kemampuan guru dalam memilih metode, strategi dan model yang tepat. Kemudian persamaan yang dapat diperolah ialah tentang gaya mengajar yang sangat berdampak pada hasil belajar peserta didik dan motivasi peserta didik. Adanya perubahan gaya mengajar diharapkan mampu untuk mengembangkan perangkat pembelajran yang akan diberikan ke peserta didik.

Keluarnya ijin pelaksanaan pembelajaran tatap muka dengan keadaan peserta didik yang notabennya sudah mengalami penurunan hasil belajar dan motivasi belajar akibat pembelajaran daring. Disinilah tantangan guru, dituntut agar bisa membangkitkan kembali semangat belajar peserta didik, meningkatkan kembali hasil belajar peserta didik dan bisa memotivasi peserta didik untuk aktif dalam proses pembelajaran. Berikut beberapa hal yang dapat dilakukan untuk merangsang peserta didik belajar aktif dikelas, serta bisa digunakan untuk menarik simpati peserta didik dalam proses belajar mengajar 
284 Meningkatan Motivasi Belajar Peserta Didik pada Pembelajaran Tatap Muka Usai Belajar Online Akibat Pandemi Covid-19- Syarifuddin, St Aisyah, Yuli Triana

DOI: https://doi.org/10.31004/edukatif.v4i1.1700

\section{A. Media pembelajaran yang menarik}

Media merupakan suatu alat bantu yang dapat digunakan pada proses belajar mengajar. (Dale, 1969) dalam bukunya "Audio Visual Methods in teaching" Edgar Dale membuat klasifikasi dari yang paling berpengaruh sampai yang tidak terlalu berpengaruh langsung.

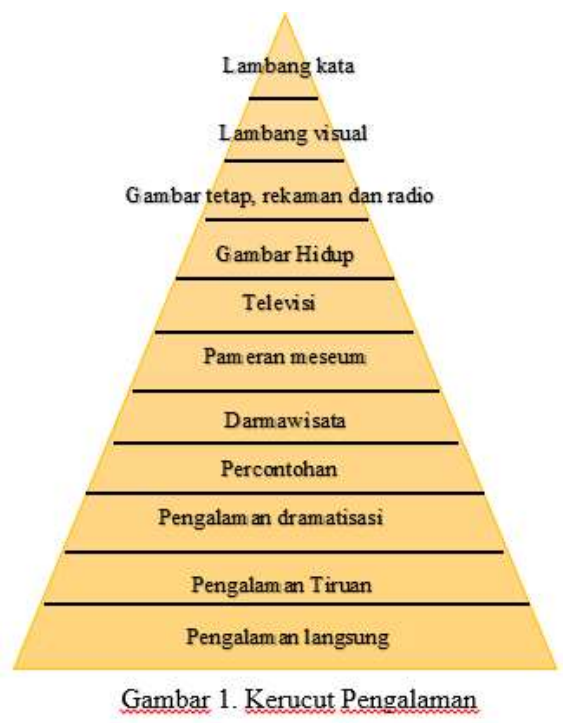

Klasifikasi diatas dimanakan "kerucut pengalaman". Kalsifikasi tersebut secara luas digunakan dalam menentukan media yang paling sesuai untuk pengalaman belajar. Fungsi penerapannya ialah untuk (1) menyewujudkan pembelajran yang efektif, (2) menciptakan suasana pebelajaran yang diinginkan, (3) Mempercepat proses belajar, (4) meningkatkan kualitas proses pembelajaran dikelas (5) kelas jadi lebih efektif. Pemanfaatan media bisa membangkitkan minat peserta didik dan rangsangan kegiatan belajar sehingga akan berpengaruh langsung pada psikologis peserta didik (Herliandry, et al., 2020). (Sadikin \& Hamidah, 2020) dan (Wahyono, et al., 2020) mengatakan ada beberapa manfaat media dalam proses pebelajaran di kelas yaitu: (1) memberikan motivasi belajar pada peserta didik karena proses pembelajrannya menarik perhatian mereka, (2) makna bahan ajar akan lebih bermakna, (3) metode pembelajaran akan lebih efektif dan bervariatif, (4) Peserta didik cenderung lebih aktif.

Media terbagi menjadi beberapa klasifikasi yaitu media visual, gerak, audio. Sebagai seorang pendidik diharuskan juga untuk bisa menganalisa penggunaan media yang seperti apa yang cocok dengan kebutuhan peserta didiknya. Adapun bentuk penyajian dan cara menyajiannya dapat dikalsifikasikan meliputi 7 kelompok:

1. grafis, bahan cetak, dan gambar diam

2. media proyeksi diam

3. Media audio

4. media audio visual diam

5. media audio visual hidup/film

6. media televisi

7. Multi media

Hal yang perlu diperhatikan dalam merencanakan penggunaan media:

1. Identifikasi karakteristik peserta didik

Dalam hal ini menlihat bagaimana kemampuan peserta didik, keterampilan peserta didik dan sikap peserta didik yang kita inginkan agar dikuasai peserta didik. 
285 Meningkatan Motivasi Belajar Peserta Didik pada Pembelajaran Tatap Muka Usai Belajar Online Akibat Pandemi Covid-19- Syarifuddin, St Aisyah, Yuli Triana

DOI: https://doi.org/10.31004/edukatif.v4i1.1700

2. Tentukan tujuan pembelajaran

Media akan disesuaikn dengan apa yang ingin dituju pada suatu pembelajaran

3. Memilih dan merancang media pembelajaran

Ada 3 hal yang bisa dilakukan yaitu : a. memilih media pembelajaran yang sudah tersedia, b, merubah media yang sudah ada, c. merancang pembuatan media yang baru

4. Menetukan materi

Kaitkan media yang akan diterapkan dengan materi ajar yang akan disampaikan ke peserta didik agar memudahkan peserta didik mudah memahami materi

5. Evaluasi

Lakukanlah evaluasi untuk mengukur seberapa efesien media pembelajaran yang digunakan

\section{B. Motivasi Belajar}

Menurut (Dewi, 2020) motivasi diartikan sebagai kekuatan, dorongan, kebutuhan, semangat, tekanan, atau mekanisme psikologis yang mendorong seseorang atau sekelompok orang untuk mencapai prestasi tertentu sesuai dengan apa yang dikehendakinya. (Cahyani, et al., 2020) mengemukakan pengertian motivasi adalah suatu dorongan kehendak yang menyebabkan seseorang melakukan suatu perbuatan untuk mencapai tujuan tertentu.

(Huitt, 2001)mengatakan motivasi adalah suatu kondisi atau status internal (kadang-kadang diartikan sebagai kebutuhan, keinginan, atau hasrat) yang mengarahkan perilaku seseorang untuk aktif bertindak dalam rangka mencapai suatu tujuan. Ditambahkan Gray (Handayani \& Irawan, 2020) mengemukakan bahwa motivasi merupakan sejumlah proses, yang bersifat internal atau eksternal bagi seorang individu, yang menyebabkan timbulnya sikap antusiasme dan persistensi, dalam hal melaksanakan kegiatan- kegiatan tertentu. Menurut (Fitriyani, et al., 2020), untuk mengetahui kekuatan motivasi belajar peserta didik, dapat dilihat dari beberapa indicator sebagai berikut : a) Kuatnya kemauan untuk berbuat b) Jumlah waktu yang disediakan untuk belajar c) Kerelaan meninggalkan kewajiban atau tugas yang lain d) Ketekunan dalam mengerjakan tugas. Sedangkan menurut (Wiguna, et al., 2020) motivasi belajar memiliki indikator sebagai berikut: a) Tekun menghadapi tugas. b) Ulet menghadapi kesulitan (tidak lekas putus asa) c) Menunjukan minat terhadap bermacam-macam masalah orang dewasa. d) Lebih senang bekerja mandiri e) Cepat bosan pada tugas rutin f) Dapat mempertahankan pendapatnya Berdasarkan beberapa pendapat di atas, motivasi dapat diartikan sebagai kekuatan (energi) seseorang yang dapat menimbulkan tingkat kemauan dalam melaksanakan suatu kegiatan.Kemauan baik yang bersumber dari dalam diri individu itu sendiri (motivasi intrinsik) maupun dari luar individu (motivasi ekstrinsik). Seberapa kuat motivasi yang dimiliki individu akan banyak menentukan kualitas perilaku yang ditampilkannya, baik dalam konteks belajar, bekerja maupun dalam kehidupan lainnya.

\section{Upaya Meningkatkan Motivasi Belajar}

Upaya meningkatkan motivasi belajar anak dalam kegiatan belajar di sekolah, ada beberapa langkah yang dapat dilakukan oleh guru diungkapkan (Lestari \& Gunawan, 2020) yaitu:

1. Memberi Penghargaan Angka

Angka dalam hal ini sebagai simbol dari nilai kegiatan belajarnya. Banyak peserta didik yang justru untuk mencapai angka/nilai yang baik. Sehingga yang dikejar hanyalah nilai ulangan atau nilai raport yang baik.Angka-angka yang baik itu bagi para peserta didik merupakan motivasi yang sangat kuat. Yang perlu diingat oleh guru, bahwa pencapaian angka-angka tersebut belum merupakan hasil belajar yang sejati dan bermakna. Harapannya angka-angka tersebut dikaitkan dengan nilai afeksinya bukan sekedar kognitifnya saja. 
286 Meningkatan Motivasi Belajar Peserta Didik pada Pembelajaran Tatap Muka Usai Belajar Online Akibat Pandemi Covid-19- Syarifuddin, St Aisyah, Yuli Triana

DOI: https://doi.org/10.31004/edukatif.v4i1.1700

\section{Hadiah}

Dapat menjadi motivasi yang kuat, dimana peserta didik tertarik pada bidang tertentu yang akan diberikan hadiah. Tidak demikian jika hadiah diberikan untuk suatu pekerjaan yang tidak menarik menurut peserta didik.

\section{Kompetisi}

Persaingan, baik yang individu atau kelompok, dapat menjadi sarana untuk meningkatkan motivasi belajar. Karena terkadang jika ada saingan, peserta didik akan menjadi lebih bersemangat dalam mencapai hasil yang terbaik.

\section{Ego-Involvement}

Menumbuhkan kesadaran kepada peserta didik agar merasakan pentingnya tugas dan menerimanya sebagai tantangan sehingga bekerja keras adalah sebagai salah satu bentuk motivasi yang cukup penting. Bentuk kerja keras peserta didik dapat terlibat secara kognitif yaitu dengan mencari cara untuk dapat

5. Memberi Ulangan

Para peserta didik akan giat belajar kalau mengetahui akan diadakan ulangan. Tetapi ulangan jangan terlalu sering dilakukan karena akan membosankan dan akan jadi rutinitas belaka.

\section{Mengetahui Hasil}

Mengetahui hasil belajar bisa dijadikan sebagai alat motivasi. Dengan mengetahui hasil belajarnya, peserta didik akan terdorong untuk belajar lebih giat. Apalagi jika hasil belajar itu mengalami kemajuan, peserta didik pasti akan berusaha mempertahankannya atau bahkan termotivasi untuk dapat meningkatkannya. 7. Pujian

Apabila ada peserta didik yang berhasil menyelesaikan tugasnya dengan baik, maka perlu diberikan pujian. Pujian adalah bentuk reinforcement yang positif dan memberikan motivasi yang baik bagi peserta didik. Pemberiannya juga harus pada waktu yang tepat, sehingga akan memupuk suasana yang menyenangkan dan mempertinggi motivasi belajar serta sekaligus akan membangkitkan harga diri.

8. Hukuman

Hukuman adalah bentuk reinforcement yang negatif, tetapi jika diberikan secara tepat dan bijaksana, bisa menjadi alat motivasi.Oleh karena itu, guru harus memahami prinsipprinsip pemberian hukuman tersebut.

Faktor-faktor yang mempengaruhi motivasi berprestasi (Ananda,et al., 2021) mengatakan bahwa ada beberapa faktor yang mempengaruhi motivasi berprestasi, yaitu sebagai berikut:

1. Pengalaman pada tahun-tahun pertama kehidupan

Adanya perbedaan pengalaman masa lalu pada setiap orang menyebabkan terjadinya variasi terhadap tinggi rendahnya kecenderungan untuk berprestasi pada diri seseorang.

2. Latar belakang budaya tempat seseorang dibesarkan

Bila dibesarkan dalam budaya yang menekankan pada pentingnya keuletan, kerja keras, sikap inisiatif dan kompetitif, serta suasana yang selalu mendorong individu untuk memecahkan masalah secara mandiri tanpa dihantui perasaan takut gagal, maka dalam diri seseorang akan berkembang hasrat berprestasi yang tinggi.

3. Peniruan tingkah laku (Modelling)

Melalui modelling, anak mengambil atau meniru banyak karakteristik dari model, termasuk dalam kebutuhan untuk berprestasi jika model tersebut memiliki motivasi tersebut dalam derajat tertentu.

4. Lingkungan tempat proses

Pembelajaran berlangsung Iklim belajar yang menyenangkan, tidak mengancam, memberi semangat dan sikap optimisme bagi peserta didik dalam belajar, cenderung akan mendorong seseorang untuk tertarik belajar, memiliki toleransi terhadap suasana kompetisi dan tidak khawatir akan kegagalan. 
287 Meningkatan Motivasi Belajar Peserta Didik pada Pembelajaran Tatap Muka Usai Belajar Online Akibat Pandemi Covid-19- Syarifuddin, St Aisyah, Yuli Triana

DOI: https://doi.org/10.31004/edukatif.v4i1.1700

5. Harapan orangtua terhadap anaknya.

Orangtua yang mengharapkan anaknya bekerja keras dan berjuang untuk mencapai sukses akan mendorong anak tersebut untuk bertingkahlaku yang mengarah kepada pencapaian prestasi.

\section{KESIMPULAN}

Guru dituntut kreatif membangkitkan motivasi belajar peserta didik karena dengan guru kreatif peserta didikpun akan ikut antusias mengikuti proses pembelajran yang berlansung di kelas. Hasil belajar peserta didik juga akan meningkat karna peserta didik mampu memahami dan mengerti materi ajar yang disampaikan oleh pendidik/guru nya. Selama masa pandemi Covid-19 peserta didik banyak mengalami penurunan kemampuan akdemiknya karna dalam proses pembelajaran daring yang diterapkan peserta didik tidak memiliki motivasi yang tinggi untuk mengikuti pembelajaran, disamping itu juga peserta didik banyak yang tidak mampu mengoperasikan media daring yang dilakukan sehingga peserta didik menjadi malas belajar. Diterapkan belajar tetap muka pada 2021 ini benar-benar memberikan tugas yang berat kepada guru untuk memulai kembali menanamkan semangat belajar kepada peserta didik. Media pembelajaran yang interaktif menjadi solusi agar peserta didik dapat semangat dan termotivasi kembali untuk belajar dan berprestasi di sekolah.

\section{DAFTAR PUSTAKA}

Ananda, R., Fadhilaturrahmi, F., \& Hanafi, I. (2021). Dampak Pandemi Covid-19 Terhadap Pembelajaran Tematik Di Sekolah Dasar. Jurnal Basicedu, 5(3), 1689-1694.

Asmuni, A. (2020). Problematika Pembelajaran Daring Di Masa Pandemi Covid-19 Dan Solusi Pemecahannya. Jurnal Paedagogy, 7(4), 281-288.

Ayu, M., Sari, F. M., \& Muhaqiqin, M. (2021). Pelatihan Guru Dalam Penggunaan Website Grammar Sebagai Media Pembelajaran Selama Pandemi. Al-Mu'awanah: Jurnal Pengabdian Kepada Masyarakat, 2(1), 49-55. Retrieved From

Http://Www.Ejournal.Radenintan.Ac.Id/Index.Php/Ajpm/Article/View/8904

Cahyani, A., Listiana, I. D., \& Larasati, S. P. D. (2020). Motivasi Belajar Siswa Sma Pada Pembelajaran Daring Di Masa Pandemi Covid-19. Iq (Ilmu Al-Qur'an): Jurnal Pendidikan Islam, 3(01), 123-140.

Ciotti, M., Ciccozzi, M., Terrinoni, A., Jiang, W.-C., Wang, C.-B., \& Bernardini, S. (2020). The Covid-19 Pandemic. Critical Reviews In Clinical Laboratory Sciences, 57(6), 365-388.

Dale, E. (1969). Audiovisual Methods In Teaching.

Dewi, W. A. F. (2020). Dampak Covid-19 Terhadap Implementasi Pembelajaran Daring Di Sekolah Dasar. Edukatif: Jurnal Ilmu Pendidikan, 2(1), 55-61.

Fitriyani, Y., Fauzi, I., \& Sari, M. Z. (2020). Motivasi Belajar Mahasiswa Pada Pembelajaran Daring Selama Pandemik Covid-19. Jurnal Kependidikan: Jurnal Hasil Penelitian Dan Kajian Kepustakaan Di Bidang Pendidikan, Pengajaran Dan Pembelajaran, 6(2), 165-175.

Handayani, S. D., \& Irawan, A. (2020). Pembelajaran Matematika Di Masa Pandemic Covid-19 Berdasarkan Pendekatan Matematika Realistik. Jurnal Math Educator Nusantara: Wahana Publikasi Karya Tulis Ilmiah Di Bidang Pendidikan Matematika, 6(2), 179-189.

Herliandry, L. D., Nurhasanah, N., Suban, M. E., \& Kuswanto, H. (2020). Pembelajaran Pada Masa Pandemi 
288 Meningkatan Motivasi Belajar Peserta Didik pada Pembelajaran Tatap Muka Usai Belajar Online Akibat Pandemi Covid-19-Syarifuddin, St Aisyah, Yuli Triana

DOI: https://doi.org/10.31004/edukatif.v4i1.1700

Covid-19. Jtp-Jurnal Teknologi Pendidikan, 22(1), 65-70.

Huitt, W. (2001). Motivation To Learn: An Overview. Educational Psychology Interactive, 12.

Lestari, P. A. S., \& Gunawan, G. (2020). The Impact Of Covid-19 Pandemic On Learning Implementation Of Primary And Secondary School Levels. Indonesian Journal Of Elementary And Childhood Education, $1(2), 58-63$.

Lone, S. A., \& Ahmad, A. (2020). Covid-19 Pandemic-An African Perspective. Emerging Microbes \& Infections, 9(1), 1300-1308.

Pratama, A. P. (2021). Pengaruh Pembelajaran Daring Terhadap Motivasi Belajar Siswa Sd. Mahaguru: Jurnal Pendidikan Guru Sekolah Dasar, 2(1), 88-95.

Purnomo, H., Okarda, B., Shantiko, B., Achdiawan, R., Dermawan, A., Kartodihardjo, H., \& Dewayani, A. A. (2019). Forest And Land Fires, Toxic Haze And Local Politics In Indonesia. International Forestry Review, 21(4), 486-500.

Sadikin, A., \& Hamidah, A. (2020). Pembelajaran Daring Di Tengah Wabah Covid-19 (Online Learning In The Middle Of The Covid-19 Pandemic). Biodik, 6(2), 214-224.

Sari, A. G. (2020). Kebijakan Pemberlakuan Karantina Wilayah Sebagai Antisipasi Penyebaran Corona Virus Ditinjau Dari Undang-Undang No. 6 Tahun 2018 Tentang Kekarantinaan Kesehatan. Transparansi Hukum, 3(2).

Sari, R. P., Tusyantari, N. B., \& Suswandari, M. (2021). Dampak Pembelajaran Daring Bagi Siswa Sekolah Dasar Selama Covid-19. Prima Magistra: Jurnal Ilmiah Kependidikan, 2(1), 9-15.

Suharni, \& Purwanti. (2018). Upaya Meningkatkan Motivasi Belajar Siswa. G-Couns: Jurnal Bimbingan Dan Konseling, 3(1), 131-145.

Syachtiyani, W. R., \& Trisnawati, N. (2021). Analisis Motivasi Belajar Dan Hasil Belajar Siswa Di Masa Pandemi Covid-19. Prima Magistra: Jurnal Ilmiah Kependidikan, 2(1), 90-101.

Wahyono, P., Husamah, H., \& Budi, A. S. (2020). Guru Profesional Di Masa Pandemi Covid-19: Review Implementasi, Tantangan, Dan Solusi Pembelajaran Daring. Jurnal Pendidikan Profesi Guru, 1(1), 5165.

Wiguna, R., Sutisnawati, A., \& Lyesmaya, D. (2020). Analisis Proses Pembelajaran Siswa Berbasis Online Di Kelas Rendah Pada Masa Pandemic Covid-19. Jurnal Perseda: Jurnal Pendidikan Guru Sekolah Dasar, $3(2), 75-79$. 